\title{
HASTANELERDE İŞ KAZALARI VE ÇALIŞAN GÜVENLİĞİ: KARABÜK ŞEHİR MERKEZİ ÖRNEĞİ
}

\author{
Hakan CEBEC $\dot{I}^{1}$
}

\section{Özet}

Să̆lık sektöründe, verilen hizmetin özelliğinden kaynaklı olarak săglık çalışanları birçok iş kazasına maruz kalmaktadırlar. Bu kapsamda Sağlık Bakanlı̆̆ınca çalışan güvenliğini sağlamak adına bir takım yasal düzenlemeler yapılmıştır. Temelde bu düzenlemeler hastanelerde çalışan güvenliğinin sağlanmasında hastane yönetimine, çalışan güvenliği komitesine ve çalışanlara sorumluluklar yüklemektedir. Sağlık çalışanlarının maruz kaldıkları iş kazaları ve çalışan güvenliği ile ilgili sorunlarının değerlendirilmesi ve çözüm yollarının aranması sürecine katkı sağlaması açısından, sağlık çalışanlarının çalışan güvenliği uygulamalarını değerlendirmeleri ve maruz kalınan iş kazalarının tespiti önem arz etmektedir. Bu öneme binaen hazırlanan araştırmanın amacl, hastanelerde çalışan güvenliğini tehdit eden ve sık karşılaşılan iş kazalarının tespit edilmesi, bu iş kazalarının oluşumunda, temelde hasta ve çalışan güvenliğini sağlamayı esas alan ve ülkemizdeki tüm sağlık kurumlarını kapsayan Sağlıkta Kalite Standartlarına göre, hastane yönetimi, çalışan güvenliği komitesi ve çalışanların sorumluluklarının çalışanlar tarafindan ayrı ayrı değerlendirilmesine olanak sağlanması ve böylece hangi bölümlerde geliştirmeye açık alanların bulunduğunun belirlenmesidir. Araştırma kapsamında Karabük il merkezindeki hastanelerde çalışan sağlık personeline anket uygulaması yapılmakta ve elde edilen verilere çeşitli analizler uygulanmaktadır. Araştırma sonucunda sağlık personelleri arasında iş kazasına maruz kalma oranının oldukça yüksek olduğu, hastanelerde olay bildirim kültürünün oluşmadı̆̆g, hastanelerde çalışan güvenliği komitelerinin amaçları doğrultusunda aktif işlemediği sonuçları ön plana çıkmaktadır. Ayrıca katılımcıların “yönetimin” çalışan güvenliği ile ilgili yükümlülüklerini değerlendirmesi ile ilgili sonuçlar incelendiğinde, “çalışan güvenliği komitesinin” ve "çalışanların” konu ile ilgili yükümlülüklerini değerlendirmelerine nazaran olumsuz değerlendirmede bulundukları görülmektedir.

Anahtar Kelimeler: İş Kazası, Çalışan Güvenliği, Sağlıkta Kalite Standartları

Jel Kodları: I11, I15, J28

\section{WORK-RELATED ACCIDENTS AND EMPLOYEE SAFETY IN THE HOSPITALS: AN APPLICATION AT KARABUK CITY CENTRE}

\begin{abstract}
In health sector, health care workers are exposed to a lot of work accidents as a source of the feature of the service. A set of legal arrangements have been made on the subject by the Ministry of Health is working basically assuring the safety of these arrangements, hospitals, hospital management, employee safety committee and a

\footnotetext{
${ }^{1}$ Karabük İl Sağl1k Müdürlüğü, cebecihakan78@,hotmail.com
} 
number of employees responsibilities. Evaluation of the work-related accidents which the health care workers are exposed to and safety issues related to working in health care workers and to contribute to the process of searching for solutions, applications, reviews of health care workers and detection of exposure to work-related accidents are important to employee safety. Virtue of this importance, the aim of our research, which threaten the security of working in hospitals and to identify the most common work-related accidents, accidents at work in the formation of this, according to the Service Quality Standards which essentially based on to provide patient and employee safety and to include all the health institutions in the country, hospital management, employee safety committee and responsibilities of employees and so on which provide employees the opportunity to evaluate separately by sections that determine the development of open spaces. Health personnelworking in hospitals in the city center of Karabuk scope of the research carried out and the data obtained from questionnaires were applied to various analyzes. Research of health personnel as a result of a work accident rate is quite high exposure, the culture of event notification which does not occur in hospitals, hospitals for the purposes of employee safety committees are actively committed to the fore the results. In addition, the participants 'management' obligations relating to employee safety assessment in which the assessment is unfavorable compared.

Keywords: Employee Safety, Work-Related Accident, Quality Standarts in HealthSector.

Jel Codes: I11, I15, J28

\section{GíRiş}

Günümüzde sağlık kurumları, farklı nitelik ve nicelikte uzman insan kaynağı, karmaşık iş süreçleri ve yoğun teknoloji kullanımı ile yüksek riskli mekanlar olarak göze çarpmaktadırlar. Bununla beraber sağlık sektörü de, çalışanlarının bir taraftan sağlık hizmetini sunarken diğer taraftan hizmetin özelliğinden kaynaklanan nedenlerle maruz kaldıkları risk ve tehlikelerden dolayı, gerek ulusal mevzuatımızda gerekse konuyla ilgili literatürde en riskli iş kollarından birisi olarak tanımlanmaktadır (Devebakan, 2007:4).

Sağlık bütünlügüünü kaybetmiş bir insanın tekrar sağlığına kavuşması sağlık kurumlarının, sağlık hizmetlerinin ve sağlık çalışanlarının varlığı ile mümkündür. Sağlık kurumlarında gereği gibi sağlık hizmet sunumunun sağlanması ise hizmeti verenlerin bedenen, ruhen ve sosyal yönlerden iyilik halinde olmasına yani sağlıklı çalışana ve güvenli çalışma ortamına bağlıdır. Çalışan güvenliği, çalışan sağlığının, çalışan sağlı̆̆ ise arzulanan sağlık hizmet sunum kalitesinin en önemli gerekliliğidir.

Hastanelerde çalışan ve hasta güvenliğinin sağlanması ve korunması için Sağlık Bakanlığınca Hasta ve Çalışan Güvenliğini Sağlanmasına Dair Yönetmelik ve Çalışan Güvenliği Genelgesi ile bir takım yasal düzenlemeler yapılmıştır. Bu düzenlemelerin hastanelerde güvenlik kültürü olarak benimsenmesi ve uygulanmasında kılavuzluk yapmak üzere de Sağlıkta Kalite Standartları kullanılmaktadır. Temelde bu düzenlemeler, hastanelerimizde çalışan güvenliğinin sağlanmasında hastane yönetimine, çalışan güvenliği komitesine ve çalışanlara bir takım 
sorumluluklar yüklemektedir. Buna göre hastanelerde çalışan güvenliğinin sağlanması hastane yönetiminin, çalışan güvenliği komitesinin ve çalışanların yükümlülüklerini yerine getirmesiyle sağlanacaktır.

Yüksek riskli bir iş kolu olan sağlık sektöründe, yüksek riskli mekanlar olan hastanelerde çalışan sağlık personellerinin, öncelikle kendi güvenliğgi, sonrasında hasta güvenliği için, çalışan güvenliği uygulamalarını hukuki bir zorunluluk ve kültürel bir değişim olarak benimsemeleri ve uygulamaları gerekmektedir (Hakeri, 2010:59).

\section{HASTANELERDE İŞ KAZALARI VE ÇALIŞAN GÜVENLİĞİ}

\section{1.İș Kazaları}

Dünya Sağlık Örgütü (WHO) iş kazasını “önceden planlanmamış, çoğu zaman yaralanmalara, makina ve teçhizatın zarara uğramasına veya üretimin bir süre durmasına yol açan olay” olarak tanımlamaktadır. Ulusal Çalışma Örgütü (ILO) ise, iş kazasını, "belirli bir zarar veya yaralanmaya yol açan, önceden planlanmamış beklenmedik bir olay" şeklinde tanımlamaktadır (Özkılıç, 2005:8).

Uluslararası Çalışma Örgütünün (ILO) istatistiklerinde, her yıl 210.000’i ölümcül olmak üzere 120.000.000 iş kazası olduğu belirtilmektedir. Aynı zamanda her bir saniyede dünya üzerinde 3 iş kazası olduğu ve her 3 dakikada 1 kişinin bu kazalardan dolayı öldüğü bildirilmektedir. Ülkemizde de iş kazaları ve meslek hastalıkları son derece önemli bir sorundur. SGK istatistiklerine gore; ülkemizde her yıl ortalama 70.000-80.000 iş kazası meydana gelmektedir. Bu kazalar sonucu; ortalama 1000 çalışanımız hayatını kaybetmekte, çok sayıda çalışan geçici ya da sürekli iş göremez duruma düşmektedir.6331 Sayılı İş Sağlığı ve Güvenliği Kanun tasarısında; Ülkemizde iş sağlığı ve güvenliği alanında Sosyal Güvenlik Kurumu (SGK) 2012 yılı verilerine göre; günde yaklaşık 205 iş kazası geçirmekte, iş kazası sonucu 3 işçi hayatını kaybetmekte ve 5 kişi iş göremez hale gelmektedir. Bu rakamların yanı sıra SGK istatistiklerine yansımayan, kapsam ve kayıt dışı iş kazaları ve meslek hastalıkları sonucu kayıplar da ayrıca dikkate alınmalıdır. Ülkemiz iş kazaları istatistiklerinde ne yazık ki, Avrupa'da ilk, dünyada ise 3. sirada yer almaktadır (Alpsoy, 2013:211-212).

İş kazalarının önlenmesi için, iş kazaları henüz ortaya çıkmadan önce tehlikenin kaynağında kontrol altına alınması, riskleri asgari düzeye indirecek şekilde çalışma sistemlerinin ergonomik tasarımı, kişisel koruyucu ekipman kullanımının sağlanması ve yaygınlaştırılması ve 
en önemlisi de örgüt yönetimi ve çalışanlar tarafından konunun sahiplenmesi önem taşımaktadır (Dursun, 2011:23).

\subsection{Sağlık Alanında İş Kazası ve Çalışan Güvenliği}

Amerikan Çalışma İstatistikleri Bürosu'na göre (Bureau of Labor Statistics- BLS) Amerika'da sağlık çalışanlarının maruz kaldığı iş kazası ve meslek hastalıklarının oranı, ağır sanayide gerçekleşen iş kazası ve meslek hastalıkları oranına eşit ya da daha yüksektir. Amerika'da hastanelerde tam zamanlı olarak çalışan her 100 sağlık çalışanından 8,8'i, iş kazasına/meslek hastalığına yakalanmakta veya işinden uzaklaşmaktadır. Madencilik sektöründe bu oran her 100 çalışanda 4, inşaat sektöründe her 100 çalışanda 7,9 ve üretim sektöründe her 100 çalışanda 8,1'dir. Bu veriler göz önüne alındığında sağlık çalışanları açısından iş kazaları ve meslek hastalıklarının önemi daha da iyi anlaşılmaktadır (Devebakan, 2007:141)

Hasta Hakları Yönetmeliği'nin 37. maddesine göre, “herkesin, să̆llk kurum ve kuruluşlarında güvenlik içinde olmayı bekleme ve bunu istemek hakları vardır". Bu hak sadece hastalar bakımından geçerli olmayıp, aynı zamanda sağlık çalışanları bakımından da geçerlidir.Unutulmamalıdır ki, hastaların güvende olması, öncelikle sağlık çalışanlarının sağlıklı ve güvende olmasına bağlıdır (Hakeri, 2010:53).

Dünya Sağlık Örgütünün (WHO) yaptığı tanıma göre çalışan güvenliği, çalışanların fiziki, ruhsal ve sosyal durumlarının en üst düzeye taşınması, sağlıklarına gelebilecek zararların en aza indirilebilmesi için koruma yöntemlerinin uygulanması, kişinin işine ve işin kişiye uygunluğudur.

Sağlık sektöründe çalışan güvenliği faaliyetlerindeki amaç; tüm kurum personelinin çalışma ortamı ve yaptıkları işlerden dolayı karşılaşabilecekleri tehlikeleri tanımlamak, risklerin değerlendirilmesini yapmak ve koruyucu önlemler almak esasına dayanır(Akgün, 2011:94, ctf.edu.tr, 2012).

\subsection{Sağlık Bakanlığınca Yapılan Düzenlemeler}

Bir taraftan sağlik hizmeti sunarken diğer taraftan hizmetin özelliğinden kaynaklanan nedenlerden dolayı bir takım risk ve tehlikelere maruz kalan sağlık çalışanlarını, bu risk ve tehlikelere karşı korumaya yönelik Sağlık Bakanlığınca "Hasta ve Çalışan Güvenliğinin Sağlanmasına Dair Yönetmelik ve Çalışan Güvenliği Genelgesi” ile bir takım düzenlemeler yapılmıştır. $\mathrm{Bu}$ düzenlemelerin hastanelerde güvenlik kültürü olarak benimsenmesinin ve uygulanmasının karşılığı olarak da Sağlıkta Kalite Standartları görülmektedir. Hasta ve çalışan 
güvenliğinin sağlanmasına dair yönetmeliğin 5. Maddesinde "sağlık kurumları, hasta ve çalışan güvenliğini sağlamaya yönelik gerekli faaliyetleri gerçekleştirmek amacıyla, kendi iç düzenlemelerini yapmak ve tedbirleri almakla yükümlüdür. Sağlık kurumları, hasta ve çalışan güvenliğine ilişkin tedbirleri alırken ve düzenlemeleri yaparken Daire Başkanlığınca hazırlanan ve Bakanlığın resmî internet sayfasında yayımlanan Hizmet Kalite Standartlarını esas alır” denilmektedir.

Sağlıkta Kalite Standartları, çalışan güvenliği ile ilgili olarak öngörülen düzenlemelerle hastanelerde gerekli düzenlemelerin yapılmasını, belirlenen programın yürütülmesinin sağlanmasını ve personelin iş güvenliğine yönelik farkındalığın artırılmasını amaçlamaktadır. Temelinde hasta ve çalışan güvenliği yatan ve ulusal bazda tüm sağlık kuruluşlarında sunulan hizmet kalitesinin standartlarını belirleyen, Sağlıkta Kalite Standartları hastanelerde çalışanlar için güvenli çalışma ortamlarının sağlanması adına hastane yönetimine, çalışan güvenliği komitesine ve çalışanlara bir takım sorumluluklar yüklemektedir (performans.saglik.gov.tr, 2012).

Sağlık Bakanlığı, sağlık kurumlarında çalışan güvenliğinin sağlanması adına, Sağl1kta Kalite Standartları ile hastane yönetiminin, çalışan güvenliği komitesinin ve çalışanların sorumluluklarını şu şekilde belirlemiştir.

Hastane yönetimi, çalışan güvenliğinin sağlanması konusunda sorumludur ve çalışanların güvenliğinin sağlanması için yapılan tüm çalışmalara öncelik etmelidir. Yöneticiler öncelikle çalışanların kendilerini güvende hissedebilecekleri ortamlar oluşturmalıdır. Bu amaçla çalışanlar ile arasında iyi bir iletişim ağı oluşturmall, çalışanların yaptıkları işler ve verilen görevler hakkında bilgilendirmelerini tam ve net olarak yapmalı ayrıca çalışanları takdir etmelidir. Hastane üst yönetimi hastanelerde bu süreçleri gerçekçi bir şekilde yapmak için hastanede görevini tam anlamıyla yerine getiren kişilerden oluşan çalışan güvenliği komitesi kurmalıdır. Çalışan güvenliği komitesi, yöneticilerin çalışanlara ulaşabilen yüzü olmalıdır.

Meslek gruplarının temsilcilerinden oluşan çalışan güvenliği komitesi çalışan güvenliğinin să̆lanmasında merkezi bir rol oynamaktadır. Çalışan güvenliği komitesi, çalışanların çalışma ortamlarından kaynaklanabilecek riskleri belirlemelidir. Belirlenen bu risklere yönelik koruyucu önlemleri ve tedbirleri almalıdır. Risk değerlendirmesi bölüm bazında ve çalışan bazında yapılmalıdır. Çalışan güvenliği komitesi, belirlenen risklere yönelik bölümde çalışanlar ile birlikte değerlendirmeler yaparak gereken önlemleri almalıdır. Alınan önlemlere yönelik çalışanlara ĕgitimler verilmesi sağlanmalı ve sürekli kontrol etmelidir. Çalışan güvenliği 
komitesinin en önemli görevlerinden biride Kalite Yönetim Birimine yapılan olay bildirimlerinin kendisi ile ilgili olan olaylarda kök neden analizini yapmaktır.

Çalışanlar kendi güvenliklerinin sağlanmasında önemli bir role sahiptir. Çünkü sistemi düzeltmek çalışanların elindedir. Çalışanlar, memnuniyet anketlerini gerçekçi doldurmall, olay bildiriminde bulunmalı, hastanede tüm kayıtların düzgün tutulmasını săglamalı, sağlık taramalarını takip etmeli, eğitimlere katılmal, yeni ĕgitim programları önermeli, görüş ve önerilerini komiteye bildirmelidir (Să̆llk Bakanlı̆̆l, 2011:37-38).

Belirlenen bu sorumlulukların taraflarca yerine getirilme düzeyleri, sağlık kurumlarında çalışan güvenliğinin hangi oranda sağlandığını ve hangi alanların geliştirilmesi gerektiğini gösterir. Sağlık çalışanlarının çalışan güvenliği ile ilgili sorunlarının değerlendirilmesi ve çözüm yollarının aranması sürecine katkı sağlaması açısından, sağlık çalışanlarının çalışan güvenliği uygulamalarını değerlendirmeleri önem arz etmektedir.

\section{KARABÜK ŞEHIR MERKEZINNDE BİR UYGULAMA}

\subsection{Araştırmanın Konusu}

Sağlıkta Kalite Standartları kapsamında Karabük şehir merkezinde bulunan Karabük Devlet Hastanesi, Şirinevler Devlet Hastanesi ve Kadın Doğum ve Çocuk Hastalıkları Hastanesindeki çalışan güvenliği uygulamaları ve bu uygulamaların çalışanlar tarafından nasıl değerlendirildiği bu çalışmanın konusunu içermektedir.

\subsection{Araştırmanın Amacı ve Önemi}

Temelinde hasta ve çalışan güvenliği yatan Sağlıkta Kalite Standartları hastanelerde çalışanlar için güvenli çalışma ortamlarının sağlanması adına hastane yönetimine, çalışan güvenliği komitesine ve çalışanlara bir takım sorumluluklar yüklemektedir.

Araştırmamızın amacı hastanelerde çalışan güvenliğini tehdit eden ve en sık karşılaşılan iş kazalarının tespit edilmesi, bu iş kazalarının oluşumunda, mevzuat gereği ilgili tarafların (hastane yönetimi, çalışan güvenliği komitesi ve çalışanlar) sorumluluklarının çalışanlar tarafından ayrı ayrı değerlendirilmesine olanak sağlanması ve böylece hangi bölümlerde geliştirmeye açık alanların bulunduğunun belirlenmesidir.

Dünyada ve ülkemizde sağlık işletmelerinde çalışanların maruz kaldıkları risk ve tehlikelere yönelik çalışmalara sıklıkla rastlanmasına rağmen; hastanelerde çalışan güvenliği ile ilgili tarafların (hastane yöneticilerinin, çalışan güvenliği komitesinin ve çalışanların) ilgili 
mevzuat hükümleri ile belirlenen yükümlülüklerinin, çalışanlar tarafından değerlendirilmesine yönelik her hangi bir çalışmaya rastlanmamıştır.

$\mathrm{Bu}$ araştırma, hastanelerde çalışan güvenliğinin sağlanmasında sözü edilen tarafların sorumluluğunun katılımcılar tarafından değerlendirilmesi, çalışan güvenliği alanında geliştirilmeye açık hangi alanların bulunduğunun belirlenmesi ve konu ile ilgili önerilerin sunulması açısından önem taşımaktadır.

\subsection{Araştırmanın Yöntemi}

Araştırmada, araştırmacılar tarafından literatür taraması sonucu hazırlanan(Çınar ve ark.2011; Koraşl1 ve ark. 2010; Devebakan 2007; Esma 2009; Hasta ve Çalışan Güvenliğinin Sağlanmasına Dair Yönetmelik 2011; Hastane HKS 2008, HKS Okulu Ders Notları) ve beş bölümden oluşan anket formu kullanılmıştır. Veriler 1-15 Mayıs 2012 tarihlerinde Karabük Devlet Hastanesinde, Şirinevler Devlet Hastanesinde ve Kadın ve Çocuk Hastalıkları Hastanesinde yüz yüze yapılan görüşmeler sonucu toplanmıştır. Sorular beşli likert ölçeğine göre kesinlikle katılmıyorum ile kesinlikle katılıyorum aralığında değerlendirilmiştir. İfadelerin tamamı pozitif olarak hazırlanmıştır. Anket formu 5 bölüm 39 ifadeden oluşmaktadır. Bu bölümler aşağıdaki gibi ele alınmıştır.

1. Sosyo-demografik özellikler,

9 madde

2. İş kazaları,

9 madde

3. Yönetimin sorumluluğu,

7 madde

4. Çalışan güvenliği komitesinin sorumluluğu,

7 madde

5. Çalışanların sorumluluğu,

7 madde

Araştırmanın ana kütlesi Karabük il merkezinde faaliyet gösteren, Karabük Devlet Hastanesi, Şirinevler Devlet Hastanesi ile Kadın ve Çocuk Hastalıkları Hastanesi'nde çalışan tüm sağlık çalışanlarından oluşmaktadır (630 kişi). Araştırmada tam sayım yöntemi uygulanmış olup, bu kapsamda ulaşılabilen 334 sağlık çalışanına anket uygulaması yapılmıştır.

Araştırmadan elde edilen veriler SPSS (Statistical Packagesfor the Social Sciences) 18.0 paket programı kullanılarak değerlendirilmiştir. Elde edilen verilere, soruların kendi arasında tutarlılığını ve kullanılan ölçeğin konuyu ne derece yansıttığını değerlendirmek amacıyla güvenilirlik ve yüzde analizi gibi tanımlayıcı analizler, çapraz tablo ve çok faktörlü varyans analizi (manova) uygulanmıştır. 
Ölçeğin genel güvenilirliği için hesaplanan Cronbach Alpha katsayısı 0,76( $\mathrm{p}=0,000<0,05)$ olarak bulunmuştur. Çalışmamızda kullandığımız ölçeğin çalışan güvenliğini değerlendirmede güvenilir olduğu tespit edilmiştir(Nakip, 2006:146).

Anket formunun ön uygulaması Haydarpaşa Numune Eğitim ve Araştırma Hastanesinde 20 çalışan üzerinde okunabilirlik ve anlaşılabilirlik yönünden test edilmiş ve katılımcıların görüşleri doğrultusunda anket formu revize edilmiştir.

\section{ARAŞTIRMADAN ELDE EDÍLEN VERILERIN ANALİİ VE} DEĞERLENDİRILMESI

\subsection{Katılımcıların Demografik Özellikleri}

Tablo 1. Katılımcıların Demografik Özellikleri

\begin{tabular}{|c|c|c|c|c|c|}
\hline Yaş & Frekans & $(\%)$ & Kurumda Çalışma Yılı & Frekans & $(\%)$ \\
\hline $19-29$ & 45 & 14,3 & 1 yıldır çalışan & 80 & 26,5 \\
\hline $30-39$ & 189 & 60,2 & 0-3 yildır çalışan & 120 & 38,7 \\
\hline $40-49$ & 71 & 22,6 & 0-5 yıldır çalışan & 159 & 51,3 \\
\hline $50+$ & 9 & 2,9 & En az 20 yıldır çalışan & 23 & 7,4 \\
\hline Cinsiyet & Frekans & $\%$ & Servis/Birim & Frekans & $(\%)$ \\
\hline Erkek & 89 & 27,6 & Ameliyathane & 36 & 12,7 \\
\hline Kadın & 233 & 72,4 & Acil & 52 & 18,3 \\
\hline & & & Yoğun Bakım & 41 & 14,4 \\
\hline Medeni Hal & Frekans & $(\%)$ & Dahili Serv. & 50 & 17,6 \\
\hline Evli & 242 & 76,1 & Cerrahi Serv. & 47 & 16,6 \\
\hline Bekar & 76 & 23,9 & Diğer & 57 & 20,1 \\
\hline Eğitim Durumu & Frekans & $(\%)$ & Meslek & Frekans & $(\%)$ \\
\hline Lise & 30 & 9,4 & Hemşire & 162 & 48,5 \\
\hline Ön lisans & 139 & 43,4 & Doktor & 52 & 15,6 \\
\hline Lisans & 98 & 30,6 & Ebe & 35 & 10,5 \\
\hline Yüksek lisans, doktora & 53 & 16,6 & Diğer (Ecz. Fizyt. Sağ. Tekn.) & 53 & 15,7 \\
\hline Kurum & Frekans & $(\%)$ & Meslekte Çalışma Yılı & Frekans & $(\%)$ \\
\hline Karabük Devlet Hastanesi & 134 & 42 & $1-10$ y1l aras1 & 93 & 29,8 \\
\hline Kadın Doğum ve Çocuk Hast. & 94 & 29,5 & $11-20$ y1l aras1 & 160 & 51,3 \\
\hline Şirinevler Devlet Hastanesi & 91 & 28,5 & 21 yıl ve üzeri & 59 & 18,9 \\
\hline
\end{tabular}


Araştırmanın demografik değişkenlerine ait tanımlayıcı istatistikler Tablol'de gösterilmiştir. Buna göre katılımcıların yaş itibarıyla 4 gruba dağıldıkları, \%72'sinin kadın, \%76'sının evli, ağırlıklı meslek grubunun hemşireler ve ağırlıklı eğitim durumunun ön lisans olduğu, kurumda çalışma yıllarına bakıldığında, çalışanların yarıdan fazlasının 1 ile 5 yıl arasında kurumda çalıştıkları anlaşılmaktadır.

\subsection{Katılımcıların Maruz Kaldıkları İş Kazalarıyla İlgili Veriler}

TBMM'nin 2011 yılında yayımlamış olduğu “işyerinde psikolojik taciz (mobbing) ve çözüm önerileri raporunda”, işyerinde psikolojik şiddetin sıklıkla yaşandığı sektörlerin başında sağlık sektörü olduğu ve sağlık çalışanlarının şiddete uğrama riskinin diğer meslek gruplarına göre 16 kat daha fazla olduğu belirlenmiştir. Raporda, İstanbul'da 505 hemşireyi kapsayan bir çalışmada da hemşirelerin \%86'sının psikolojik tacize maruz kaldığı belirtilmiştir. Bosna Hersek’te “doktorlarda mobbing ve stres üzerine yapılan bir çalışmada, ankete katılan doktorların \%75'inin mobbinge maruz kaldıkları belirtilmiştir (TBMM, 2011:16-17). Almanya'da 2009 yılında yapılan başka bir çalışmada da sağlık personelinin meslek hayatları boyunca, \% 70,7'sinin fiziksel, \%89,4'ünün ise sözel şiddete maruz kaldığı belirtilmektedir (TBMM, 2013:218). TÜRK SAĞLIK-SEN tarafından 2012 yılının başında yapılan ve 1864 sağlık çalışanının katıldığı bir araştırmaya göre ise, doktorların \%78'inin, hemşire ve ebelerin \%69’u şiddete maruz kaldıklarını bildirmektedirler. 
Tablo 2. Katılımcıların Maruz Kaldıkları İş Kazalarıyla İlgili Veriler

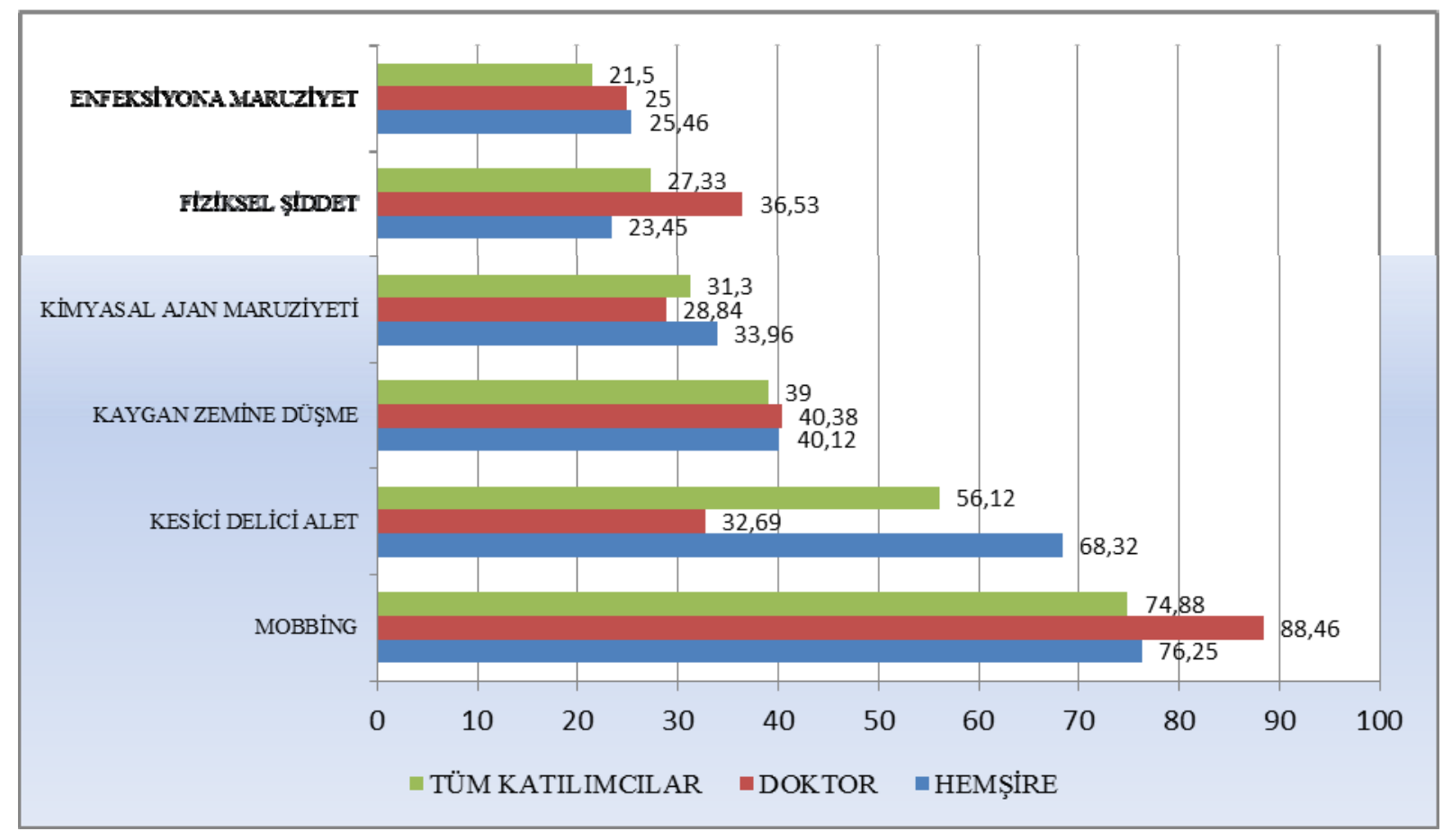

İş kazası ile ilgili bulgular incelendiğinde, literatürdeki diğer çalışmalara paralel olarak doktorların \%88'inin, hemşirelerin \%76'sının, tüm katılımcıların \% 74'ünün çalışma hayatlarında en az bir kez mobbinge uğradıkları, anlaşılmaktadır. Bununla beraber; hemşirelerin \%68'inin, doktorların \%32'sinin, tüm personelin yarısından fazlasının çalışma hayatlarında en az bir kez kesici-delici alet yaralanmalarına maruz kaldıkları, katılımcıların yaklaşık \%40'nın kaygan zeminde düştükleri, \%30'unun kimyasal ajanlara maruz kaldıkları, \%27'sinin fiziksel şiddete maruz kaldıkları, \%22'sinin enfeksiyona maruz kaldıkları anlaşılmaktadır.

Tablo 3. Son Bir Yılda Iş Kazasına Uğrayanların Olay Bildiriminde Bulunma Oranları

\begin{tabular}{|c|c|c|c|}
\hline \multirow{2}{*}{} & \multicolumn{2}{|c|}{ Kaza Bildirim } & \multirow{2}{*}{ Toplam } \\
\cline { 2 - 5 } & \multicolumn{2}{|c|}{ Evet } & \multicolumn{2}{|c|}{ Hayır } & \\
\hline Son Bir Yıılda İş Kazasına Uğrayanlar & $16 \quad \mathbf{( \% 1 7 )}$ & $80 \quad \mathbf{( \% 8 3 )}$ & 96 \\
\hline Meslek Hayatında İş Kazasına Uğrayanlar & $24 \quad \mathbf{( \% 9 )}$ & $265 \quad \mathbf{( \% 9 1 )}$ & 289 \\
\hline
\end{tabular}

Son bir yılda iş kazasına uğrayanların olay bildiriminde bulunma oranları incelendiğinde, bu soruya cevap veren 289 katılımcıdan 96'sının, son bir yıl içinde en az bir kez iş kazasına uğradığını, bunlardan 80'inin olay bildirimde bulunmadığı anlaşılmaktadır. Yani son bir yılda iş 
kazasına uğrayanların \%83'ü, meslek hayatları boyunca iş kazasına uğrayanların \%91'i olay bildiriminde bulunmamaktadir.

\subsection{Katılımcıların Çalışan Güvenliğinin Sağlanmasında "Yönetimin Sorumluluklarına" Dair İfadelere Verdikleri Cevaplar}

Tablo 4. Katılımcılara Göre Çalışan Güvenliğinin Sağlanmasında "Yönetimin Sorumlulukları"

\begin{tabular}{|c|c|c|c|c|c|c|c|c|c|c|}
\hline & & \multirow{4}{*}{ İFADELER } & \multirow{4}{*}{ Ortalama* } & \multirow{4}{*}{$\begin{array}{c}\text { Standart } \\
\text { Sapma }\end{array}$} & \multirow{4}{*}{$\mathrm{N}$} & \multicolumn{5}{|c|}{ CEVAPLARIN DAĞILIMI* } \\
\hline & & & & & & 1 & 2 & 3 & 4 & 5 \\
\hline & & & & & & Frekans & Frekans & Frekans & Frekans & Frekans \\
\hline & & & & & & $\%$ & $\%$ & $\%$ & $\%$ & $\%$ \\
\hline \multirow{8}{*}{ 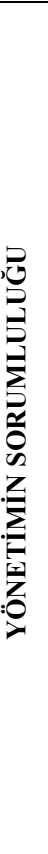 } & 1 & $\begin{array}{l}\text { Bu birimde fiziksel saldırılara karşı gerekli tedbirler } \\
\text { alınmıştır }\end{array}$ & 2,67 & 1,273 & 306 & $\begin{array}{l}69 \\
\% 22,5\end{array}$ & $\begin{array}{l}91 \\
\% 29,7\end{array}$ & $\begin{array}{l}36 \\
\% 11,8\end{array}$ & $\begin{array}{l}93 \\
\% 30,4\end{array}$ & $\begin{array}{l}17 \\
\% 5,6\end{array}$ \\
\hline & 2 & $\begin{array}{l}\mathrm{Bu} \text { birimde iş yükünün üstesinden gelecek kadar } \\
\text { personel mevcuttur. }\end{array}$ & 2,71 & 1,338 & 319 & $\begin{array}{l}72 \\
\% 22,6\end{array}$ & $\begin{array}{l}102 \\
\% 32,0\end{array}$ & $\begin{array}{l}15 \\
\% 4,7\end{array}$ & $\begin{array}{l}105 \\
\% 32,9\end{array}$ & $\begin{array}{l}25 \\
\% 7,8\end{array}$ \\
\hline & 3 & $\begin{array}{l}\text { Bu birimde çalışan güvenliğine yönelik koruyucu } \\
\text { ekipman mevcuttur. }\end{array}$ & 3,83 & 1,135 & 315 & $\begin{array}{l}22 \\
\% 7,0\end{array}$ & $\begin{array}{l}28 \\
\% 8,9\end{array}$ & $\begin{array}{l}18 \\
\% 5,7\end{array}$ & $\begin{array}{l}61 \\
\% 51,1\end{array}$ & $\begin{array}{l}86 \\
\% 27,3\end{array}$ \\
\hline & 4 & $\begin{array}{l}\text { Bu birimde çalışma mekanı fiziksel sağlığımız } \\
\text { gözetilecek şekilde düzenlenmiştir. }\end{array}$ & 2,66 & 1,316 & 317 & $\begin{array}{l}75 \\
\% 23,7\end{array}$ & $\begin{array}{l}100 \\
\% 31,5\end{array}$ & $\begin{array}{l}21 \\
\% 6,6\end{array}$ & $\begin{array}{l}100 \\
\% 31,5\end{array}$ & $\begin{array}{l}21 \\
\% 6,6\end{array}$ \\
\hline & 5 & $\begin{array}{l}\text { Çalışan güvenliği ile ile ilgili } r \\
\text { yöneticilerimizce çözüme yönelik birda } \\
\text { sergilenir. }\end{array}$ & 2,83 & 1,185 & 316 & $\begin{array}{l}48 \\
\% 15,2\end{array}$ & $\begin{array}{l}90 \\
\% 28,5\end{array}$ & $\begin{array}{l}63 \\
\% 19,9\end{array}$ & $\begin{array}{l}97 \\
\% 30,7\end{array}$ & $\begin{array}{l}18 \\
\% 5,7\end{array}$ \\
\hline & 6 & $\begin{array}{l}\text { Çalışan güvenliği ile ilgili sorunların çözümünde } \\
\text { yöneticilerimiz çalışanların önerilerini ciddiye alır. }\end{array}$ & 2,91 & 1,211 & 321 & $\begin{array}{l}50 \\
\% 15,6\end{array}$ & $\begin{array}{l}76 \\
\% 23,7\end{array}$ & $\begin{array}{l}71 \\
\% 22,1\end{array}$ & $\begin{array}{l}100 \\
\% 31,2\end{array}$ & $\begin{array}{l}24 \\
\% 7,5\end{array}$ \\
\hline & 7 & $\begin{array}{l}\text { Yöneticilerimizin faaliyetleri, çalışan güvenliğinin üst } \\
\text { düzey bir öncelik olduğunu göstermektedir. }\end{array}$ & 2,78 & 1,218 & 317 & $\begin{array}{l}53 \\
\% 16,7\end{array}$ & $\begin{array}{l}92 \\
\% 29,0\end{array}$ & $\begin{array}{l}72 \\
\% 22,7\end{array}$ & $\begin{array}{l}73 \\
\% 23,0\end{array}$ & $\begin{array}{l}27 \\
\% 8,5\end{array}$ \\
\hline & \multicolumn{2}{|c|}{ Genel Ortalama } & 2,91 & & & & & & & \\
\hline
\end{tabular}

Tablo 4'deki bilgilere göre;

- Katılımcılara çalışan güvenliğinin sağlanmasında yönetimin sorumluluğu sorulduğunda, katılımcıların genel olarak olumsuz değerlendirme de bulundukları, \%46'sının "Yöneticilerimizin faaliyetleri, çalışan güvenliğinin üst düzey bir öncelik olduğunu göstermektedir" ifadesine katılmadığı, \%32'sinin katıldığ1,

- \%52'sinin “bu birimde fiziksel saldırılara karşı gerekli önlemler alınmıştır” ifadesine katılmadığ $1, \% 36$ 'sının katıldığ 1 , 
- \%44’ünün “Çalışan güvenliği ile ilgili sorunlarda yöneticilerimizce çözüme yönelik bir yaklaşım sergilenir" ifadesine katılmadığı, \%36'sının katıldı̆̆ı,

- \%55'inin “bu birimde çalışma mekanı fiziksel sağlı̆̆ımız gözetilecek şekilde düzenlenmiştir" ifadesine katılmadığ, \%38'inin katıldığ1,

- \%45'inin “bu birimde iş yükünün üstesinden gelecek kadar personel mevcuttur" ifadesine katılmadığ $1, \% 41$ 'inin katıldığı anlaşılmaktadır.

\subsection{Katılımcıların Çalışan Güvenliğinin Sağlanmasında "Çalışan Güvenliği Komitesinin" Sorumluluklarına Dair İfadelere Verdikleri Cevaplar}

Tablo 5. Katılımcılara Göre, Çalışan Güvenliğinin Sağlanmasında Çalışan Güvenliği Komitesinin Sorumluluğu

\begin{tabular}{|c|c|c|c|c|c|c|c|c|c|c|}
\hline & & & & & & & CEVAPI & $\overline{\text { ARIN DA }}$ & ĞILIMI* & \\
\hline & & & Ortalama * & Standart & $\mathrm{N}$ & 1 & 2 & 3 & 4 & 5 \\
\hline & & & & & & Frekans & Frekans & Frekans & Frekans & Frekans \\
\hline & & & & & & $\%$ & $\%$ & $\%$ & $\%$ & $\%$ \\
\hline & 1 & Hastanemizde çalışan güvenliği komitesi vardır. & 3,68 & 0,991 & 320 & $\begin{array}{l}12 \\
\% 3,8\end{array}$ & $\begin{array}{l}19 \\
\% 5,9\end{array}$ & $\begin{array}{l}95 \\
\% 29,7\end{array}$ & $\begin{array}{l}127 \\
\% 39,7\end{array}$ & $\begin{array}{l}67 \\
\% 20,9\end{array}$ \\
\hline كِ & 2 & $\begin{array}{llll}\begin{array}{l}\text { Hastanemizde } \\
\text { oluşturulmuştur. }\end{array} & \text { uyarı } & \text { güvenlik } & \text { sistemleri } \\
\end{array}$ & 4,05 & 0,958 & 322 & $\begin{array}{l}10 \\
\% 3,1\end{array}$ & $\begin{array}{l}19 \\
\% 5,9\end{array}$ & $\begin{array}{l}23 \\
\% 7,1\end{array}$ & $\begin{array}{l}164 \\
\% 50,9\end{array}$ & $\begin{array}{l}106 \\
\% 32,9\end{array}$ \\
\hline 岂 & 3 & $\begin{array}{l}\text { Uyarı güvenlik sistemlerinin hangi durumlarda ve } \\
\text { nasıl çalıştı̆ı̆ı biliyorum. }\end{array}$ & 3,87 & 0,962 & 316 & $9 \% 2,8$ & $\begin{array}{l}18 \\
\% 5,7\end{array}$ & $\begin{array}{l}61 \\
\% 19,3\end{array}$ & $\begin{array}{l}145 \\
\% 45,9\end{array}$ & $\begin{array}{l}83 \\
\% 26,3\end{array}$ \\
\hline : & 4 & $\begin{array}{l}\text { Çalışan güvenliği komitesince bölüm bazında } \\
\text { riskleri belirlemek üzere çalışan ziyaretleri } \\
\text { yapılmaktadır. }\end{array}$ & 3,07 & 1,167 & 320 & $\begin{array}{l}35 \\
\% 10,9\end{array}$ & $\begin{array}{l}66 \\
\% 20,6\end{array}$ & $\begin{array}{l}97 \\
\% 30,3\end{array}$ & $\begin{array}{l}86 \\
\% 26,9\end{array}$ & $\begin{array}{l}36 \\
\% 11,3\end{array}$ \\
\hline$\underline{\underline{w}}$ & 5 & $\begin{array}{l}\text { Çalışan güvenliği komitesince güvenlik raporlama } \\
\text { sistemi (olay bildirim sistemi) kurulmuştur. }\end{array}$ & 3,41 & 1,017 & 317 & $\begin{array}{l}17 \\
\% 5,4\end{array}$ & $\begin{array}{l}26 \\
\% 8,6\end{array}$ & $\begin{array}{l}131 \\
\% 41,3\end{array}$ & $\begin{array}{l}95 \\
\% 30,0\end{array}$ & $\begin{array}{l}48 \\
\% 15,1\end{array}$ \\
\hline$\sum_{0}^{Z}$ & 6 & $\begin{array}{l}\text { Çalışanların rutin sağlık taramaları kayıt altına } \\
\text { alınarak takip edilmektedir. }\end{array}$ & 3,50 & 1,166 & 320 & $\begin{array}{l}28 \\
\% 8,8\end{array}$ & $\begin{array}{l}35 \\
\% 10,9\end{array}$ & $\begin{array}{l}64 \\
\% 20,0\end{array}$ & $\begin{array}{l}135 \\
\% 42,2\end{array}$ & $\begin{array}{l}58 \\
\% 18,1\end{array}$ \\
\hline$\frac{4}{3}$ & 7 & $\begin{array}{l}\text { Çalışan güvenliğini sağlamaya yönelik eğitimler } \\
\text { düzenlenmektedir. }\end{array}$ & 3,73 & 1,07 & 320 & $\begin{array}{l}17 \\
\% 5,3\end{array}$ & $\begin{array}{l}27 \\
\% 8,4\end{array}$ & $\begin{array}{l}54 \\
\% 16,9\end{array}$ & $\begin{array}{l}149 \\
\% 46,6\end{array}$ & $\begin{array}{l}73 \\
\% 22,8\end{array}$ \\
\hline & & nel Ortalama & 3,61 & & & & & & & \\
\hline
\end{tabular}

Katılımcılara çalışan güvenliğinin sağlanmasında çalışan güvenliği komitesinin sorumluluğu ile ilgili ifadelere katılıp katılmadıkları sorulduğunda, katılımcıların uyarı güvenlik 
sistemi ile ilgili sorulara olumlu cevaplar verdikleri, \%84'ünün "hastanemizde uyarı güvenlik sistemleri oluşturulmuştur" ifadesine katıldıkları, \%72'sinin "uyarı güvenlik sistemlerinin hangi durumlarda ve nasıl çalıştığını biliyoruz" ifadesine katıldıkları anlaşılmaktadır.

Tablo 5 incelendiğinde, "hastanemizde çalışan güvenliği komitesi vardır" ifadesine katılanların oranının \%60 olması dikkat çekicidir. Yine katılımcıların \%61'inin “çalışan güvenliği komitesince bölüm bazında riskleri belirlemek üzere çalışan ziyaretleri yapılmaktadır” ifadesine katılmaması, hastanelerimizde çalışan güvenliği komitelerinin amaçları doğrultusunda aktif işlemediğini düşündürmektedir.

\subsection{Katılımcıların Çalışan Güvenliğinin Sağlanmasında "Çalışanların" Sorumluluklarına Dair İfadelere Verdikleri Cevaplar}

Tablo 6. Katılımcılara Göre, Çalışan Güvenliğinin Sağlanmasında, Çalışanların Sorumluluğu

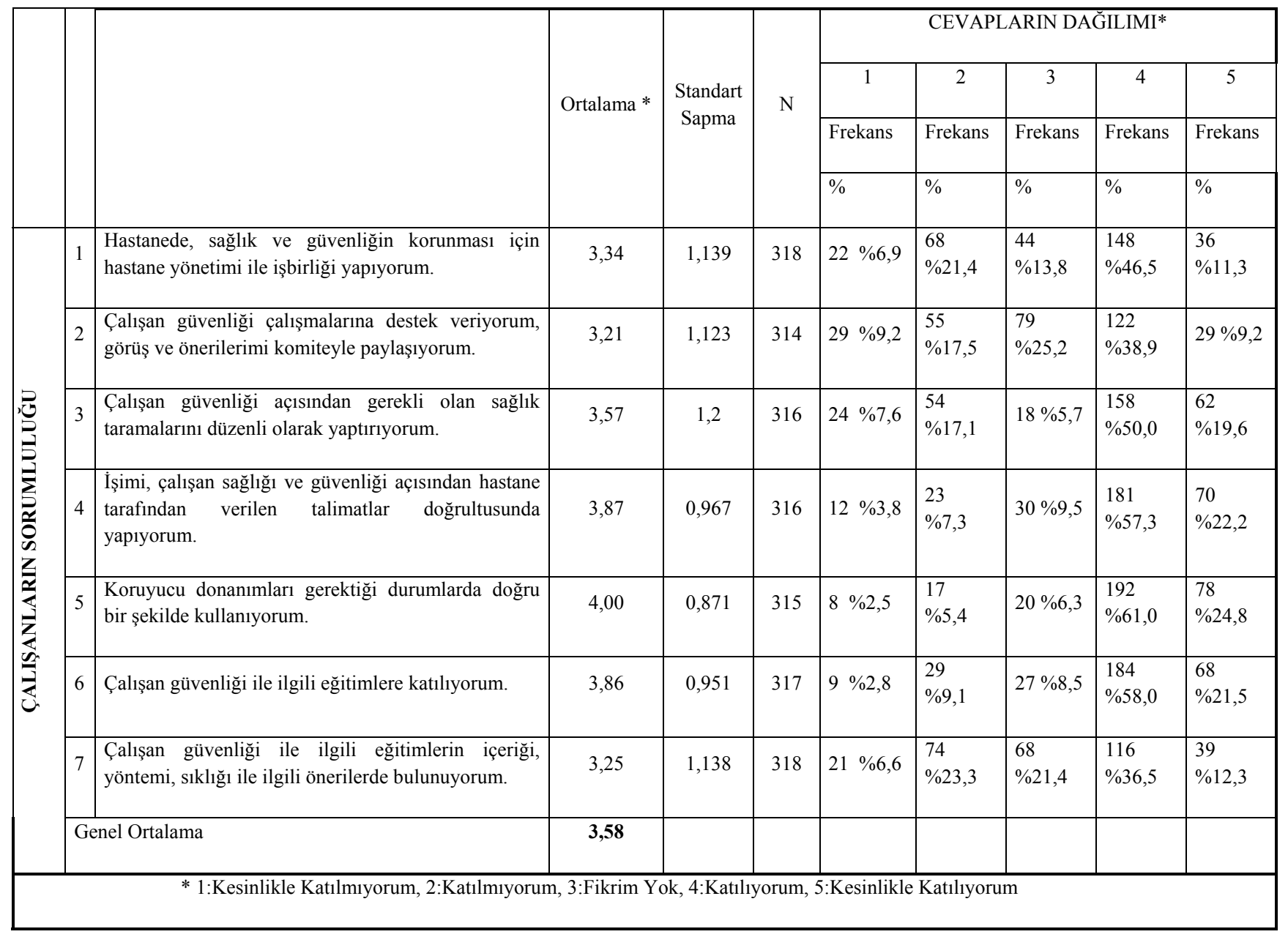


Katılımcılara çalışan güvenliğinin sağlanmasında çalışanların sorumluluğu ile ilgili ifadelere katılıp katılmadıkları sorulduğunda, en çok katıldıkları ifade "koruyucu donanımları gerektiği durumlarda doğru bir şekilde kullanıyorum” ifadesidir. Bu ifadeye katılımcıların \%86'sı katıldığını belirtmiştir. En az katıldıkları ifade ise "çalışan güvenliği çalışmalarına destek veriyorum, görüş ve önerilerimi komiteyle paylaşıyorum” ifadesidir. Katılımcıların \%51,9’unun bu ifadeye katılmadıkları anlaşılmaktadır.

Katılımcıların çalışan güvenliğinin sağlanmasında "ilgili tarafların sorumluluklarını" değerlendirmeleri ile ilgili sonuçlar incelendiğinde, çalışan güvenliği komitesinin (ortalama 3,61) ve çalışanların (ortalama 3,58) konu ile ilgili yükümlülüklerini değerlendirmelerine nazaran, yönetimin sorumluluklarına yönelik daha olumsuz değerlendirmede bulundukları görülmektedir (ortalama 2,91).

\subsection{Katılımcıların Çalıştıkları Birime/Servise Göre, Çalışan Güvenliğinin} Sağlanmasında "Yönetimin Sorumluluğunu” Algılama Düzeyleri

Katılımcıların çalıştıkları servise göre, çalışan güvenliğinin sağlanmasında "yönetimin sorumluluğunu" algılama düzeyleri bakımından anlamlı bir fark olup olmadığı MANOVA analizi ile test edilmiştir. Analiz sonuçları Tablo 7'de sunulmaktadır. Tablo 7 incelendiğinde, yoğun bakım servislerinde çalışanların, diğer çalışanlara göre çalışan güvenliğinin sağlanmasında "yönetimin sorumluluğu" ile ilgili ifadelere genel anlamda daha olumsuz cevap verdikleri görülmektedir. Ayrıca yoğun bakım servisleri çalışanlarının "bu birimde iş yükünün üstesinden gelecek kadar personel mevcuttur" ifadesine ise diğer çalışanlara göre anlamlı düzeyde farklı cevap verdikleri anlaşılmaktadır. Bu ifadeye verilen cevaplara bakıldığında, yoğun bakım servislerinde bu ifadenin ortalama değerinin diğer servislere göre 2,31 ile (katılmıyorum) en düşük değerde olduğu görülmektedir (Hotelling’s T Testi Anlamlılık Düzeyi $=\mathbf{0 , 0 3 6}<\mathbf{0 , 0 5}$ ). Bu durum ankete katılanlara göre, yoğun bakım servislerinde iş yükünün fazla olduğunu göstermektedir. 
Tablo 7. Katılımcıların Çalıştıkları Birime/Servise Göre, Çalışan Güvenliğinin Sağlanmasında "Yönetimin Sorumluluğunu" Algılama Düzeyleri

\begin{tabular}{|c|c|c|c|c|c|c|c|}
\hline \multirow{2}{*}{\multicolumn{2}{|c|}{ YÖNETIMMIN SORUMLULUĞU İFADESİ }} & \multicolumn{4}{|c|}{ Ortalamalar $^{1}$} & \multirow{3}{*}{$\begin{array}{c}\mathrm{F} \\
\text { Değeri } \\
1,005\end{array}$} & \multirow{3}{*}{\begin{tabular}{|l}
$\begin{array}{c}\text { Anlaml11ık } \\
\text { Düzeyi }\end{array}$ \\
0,392
\end{tabular}} \\
\hline & & \multirow{2}{*}{\begin{tabular}{r|}
$1 *$ \\
3,03
\end{tabular}} & \multirow{2}{*}{\begin{tabular}{|r|}
$2^{*}$ \\
2,62 \\
\end{tabular}} & \multirow{2}{*}{$\begin{array}{r}3^{*} \\
2,66\end{array}$} & \multirow{2}{*}{\begin{tabular}{|r|}
$4^{*}$ \\
2,7
\end{tabular}} & & \\
\hline 1 & Bu birimde fiziksel saldırılara karşı gerekli önlemler alınmıştır. & & & & & & \\
\hline 2 & Bu birimde iş yükünün üstesinden gelecek kadar personel mevcuttur. & $\mathbf{3 , 1 3}$ & 2,77 & 2,31 & 2,61 & 2,798 & 0,042 \\
\hline 3 & Bu birimde çalışan güvenliğine yönelik koruyucu ekipman mevcuttur. & 3,85 & 4,08 & 4,11 & 3,83 & 0,871 & 0,457 \\
\hline 4 & $\begin{array}{l}\mathrm{Bu} \text { birimde çalışma mekanı fiziksel sağlı̆̆ımız gözetilecek şekilde } \\
\text { düzenlenmiştir. }\end{array}$ & 2,65 & 2,77 & 2,37 & 2,65 & 0,667 & 0,574 \\
\hline 5 & $\begin{array}{l}\text { Çalışan güvenliği ile ilgili sorunlarda yöneticilerimizce çözüme yönelik bir } \\
\text { yaklaşım sergilenir. }\end{array}$ & 3,2 & 2,75 & 2,66 & 2,74 & 1,751 & 0,158 \\
\hline 6 & $\begin{array}{l}\text { Çalışan güvenliği ile ilgili sorunların çözümünde yöneticilerimiz çalışanların } \\
\text { önerilerini ciddiye alır. }\end{array}$ & 2,98 & 2,75 & 2,83 & 2,85 & 0,269 & 0,848 \\
\hline 7 & $\begin{array}{l}\text { Yöneticilerimizin faaliyetleri, çalışan güvenliğinin üst düzey bir öncelik } \\
\text { olduğunu göstermektedir. }\end{array}$ & 2,95 & 2,72 & 2,37 & 2,72 & 1,526 & 0,209 \\
\hline & GENEL ORTALAMA & 3,11 & 2,92 & 2,75 & 2,87 & & \\
\hline & Serbestlik Derecesi $=21,000$ & $\mathrm{Ar}$ & allilik Di & $\mathrm{yi}=\mathbf{0 , 0 3}$ & & & \\
\hline & 1-Kesinlikle Katılmıyorum, 2-Katılmıyorum, 3-Fikrim Yok, 4- Kat1lıyorum, 5- K & Kesinll & Katılly & & & & \\
\hline & 2- Acil 3-Yoğun Bakım 4-Dahili Servisler & & & & & & \\
\hline
\end{tabular}

\subsection{Katılımcıların Çalıştıkları Servise Göre, Çalışan Güvenliğinin Sağlanmasında "Çalışan Güvenliği Komitesinin Sorumluluğunu” Algılama Düzeyleri}

Katılımcıların çalıştıkları servise göre, çalışan güvenliğinin sağlanmasında "çalışan güvenliği komitesinin sorumluluğunu" algılama düzeyleri bakımından anlamlı bir fark olup olmadığı MANOVA analizi ile test edilmiştir. Analiz sonuçları Tablo 8'de verilmektedir. Tablo 8'deki bilgilere göre katılımcıların çalıştıkları servise göre, çalışan güvenliğinin sağlanmasında "çalışan güvenliği komitesinin sorumluluğunu" algılama düzeylerinin farklı olduğu anlaşılmaktadır (Hotelling's T Testi Anlamlılık Düzeyi $=\mathbf{0 , 0 1}<\mathbf{0 , 0 5}$ ). İfadelere tek tek bakılırsa, "çalışan güvenliği komitesince güvenlik raporlama sistemi kurulmuştur" ifadesinde bir farklılık olduğu görülmektedir. Bu yargıya verilen cevaplara bakıldığında, dahili servislerde bu ifadenin ortalama değerinin 3,17 ile (fikrim yok) en düşük değerde olduğu, ameliyathanede ise bu ifadenin ortalama değerinin 3,62 olduğu görülmektedir. Bu farklılığın sebebinin, daha riskli birimler olan yoğun bakım, acil ve ameliyathane servislerine göre dahili servis çalışanlarına, 
çalışan güvenliği komitesince kurulan güvenlik raporlama sisteminin anlatılamamış olduğu düşünülmektedir.

Tablo 8. Katılımcıların Çalıştıkları Birime/Servise Göre, Çalışan Güvenliğinin Sağlanmasında “Çalışan Güvenliği Komitesinin Sorumluluğunu” Algılama Düzeyleri

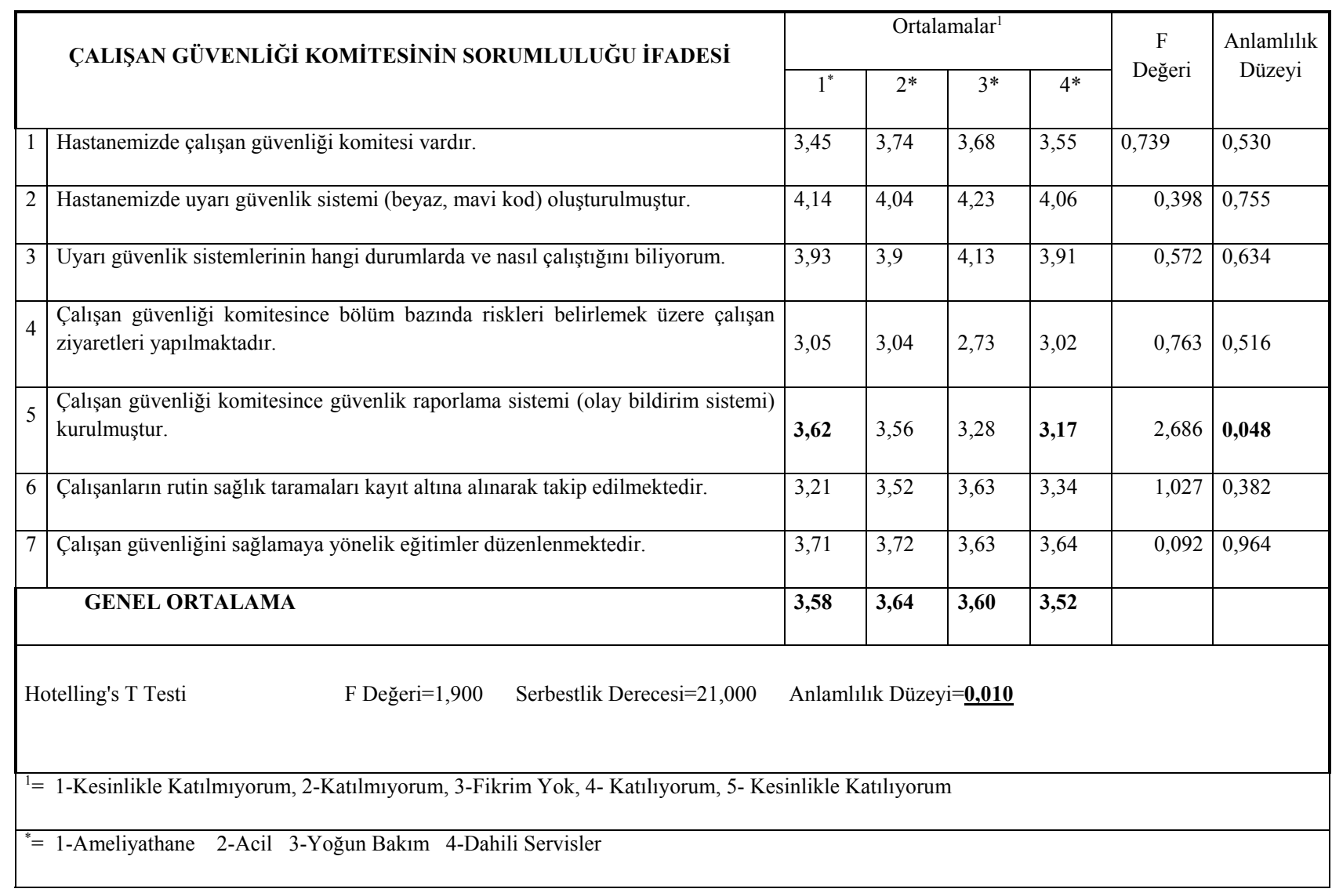

\subsection{Katılımcıların Çalıştıkları Birime/Servise Göre, Çalışan Güvenliğinin Sağlanmasında "Çalışanların Sorumluluğunu” Algılama Düzeyleri}

Katılımcıların çalıştıkları servise göre, çalışan güvenliğinin sağlanmasında "çalışanların sorumluluğunu" algılama düzeyleri farklıdır (Hotelling's T Testi Anlamlılık Düzeyi = $\mathbf{0 , 0 0 1 < 0 , 0 5 ) . ~ Y a r g ı l a r a ~ t e k ~ t e k ~ b a k ı l ı r s a , ~ " h a s t a n e d e , ~ s a g ̆ l ı g ̆ ı n ~ k o r u n m a s ı ~ i c ̧ i n ~ h a s t a n e ~ y o ̈ n e t i m i ~ i l e ~}$ işbirliği yapıyorum” yargısında anlamlı bir farklılık olduğu görülmektedir. Bu yargıya verilen cevaplara bakıldığında, yoğun bakım servislerinde bu ifadenin ortalama değerinin 2,89 ile (katılmıyorum-fikrim yok arası) en düşük değerde olduğu, acil servislerde ise bu ifadenin ortalama değerinin 3,62 (fikrim yok-katılıyorum arası) ile en yüksek değerde olduğu anlaşılmaktadır. Yine "çalışan güvenliği açısından gerekli olan sağlık taramalarını düzenli olarak yaptırıyorum" yargısında anlamlı bir farklılık olduğu görülmektedir. Buna göre yoğun bakım 
servislerinde çalışanların, "çalışan güvenliği açısından gerekli olan sağlık taramalarını düzenli olarak yaptırıyorum" yargısına katıldıkları $(4,00)$, ameliyathanelerde çalışanların ise bu konuda “fikrim yok" değerlendirmesinde bulundukları $(3,10)$ anlaşılmaktadır.

Tablo 9. Katılımcıların Çalıştıkları Birime/Servise Göre, Çalışan Güvenliğinin Sağlanmasında "Çalışanların Sorumluluğunu” Algılama Düzeyleri

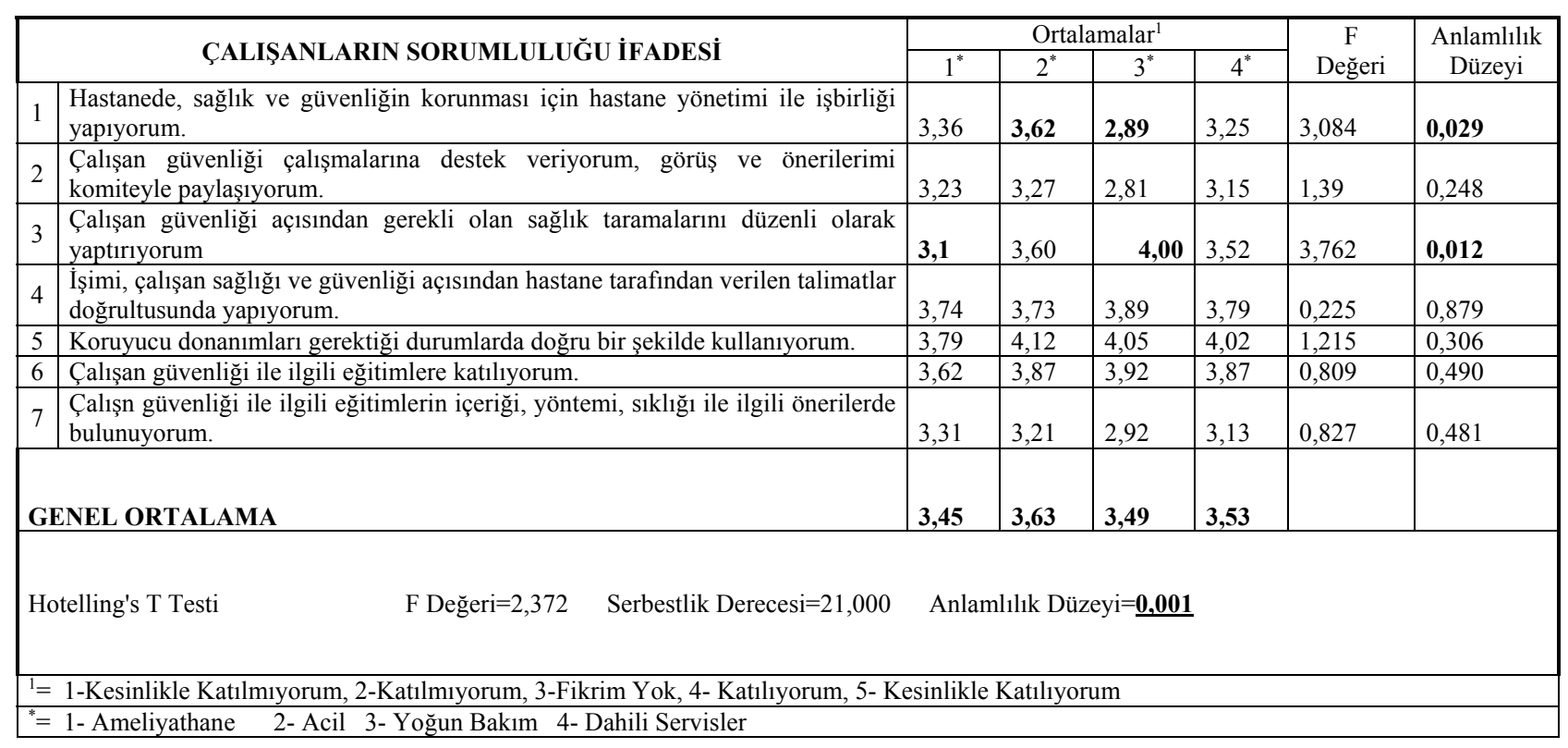

\section{9. Çalışma Hayatlarında En Az Bir İş Kazasına Uğrayan Katılımcıların, Çalışan Güvenliğinin Sağlanmasında "Yönetimin Sorumluluğunu" Algılama Düzeyleri}

Tablo 10. Çalışma Hayatlarında En Az Bir İş Kazasına Uğrayan Katılımcıların, Çalışan Güvenliğinin Sağlanmasında "Yönetimin Sorumluluğunu” Algılama Düzeyleri

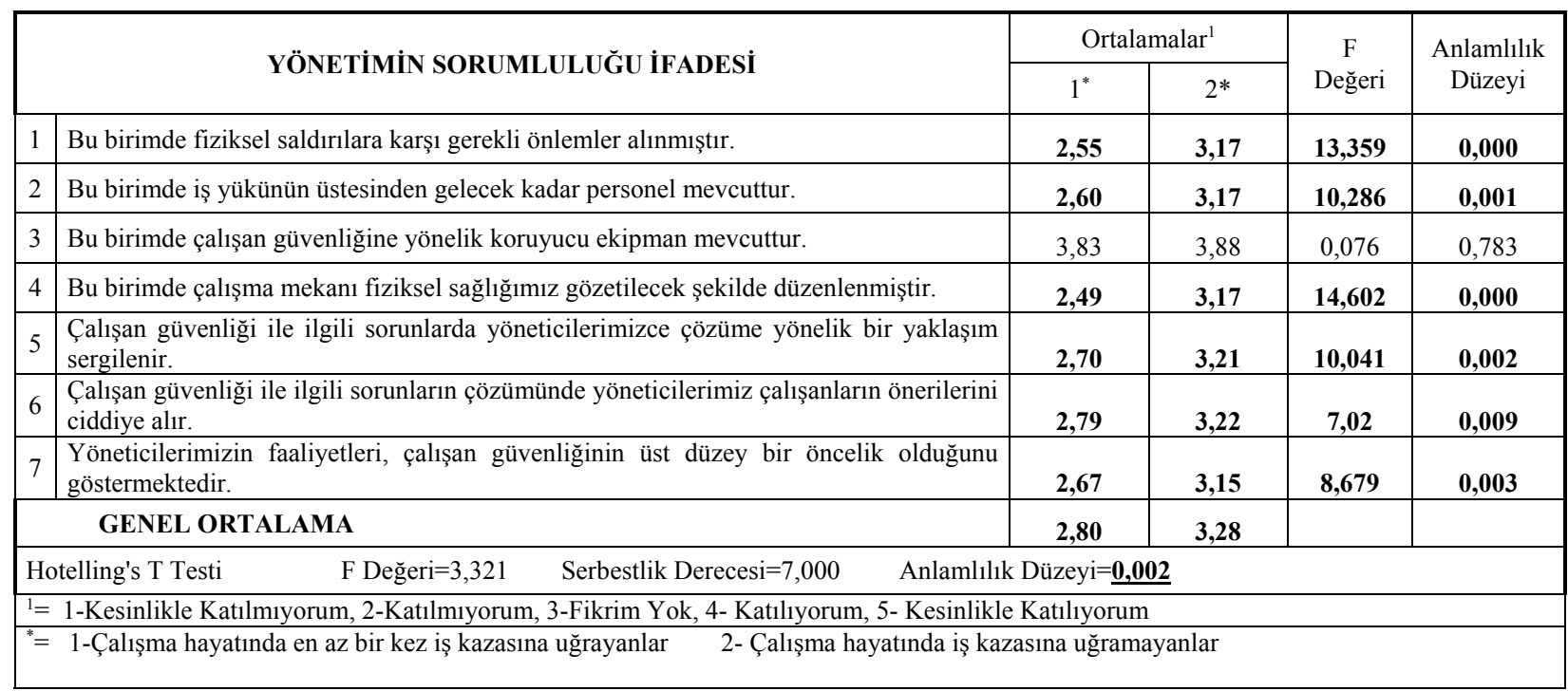


Çalışma hayatlarında en az bir iş kazasına uğrayan katılımcıların, çalışma hayatlarında hiç iş kazasına uğramayanlara göre, çalışan güvenliğinin sağlanmasında "yönetimin sorumluluğunu" algılama düzeyleri farklıdır (Hotelling's T Testi Anlamlılık Düzeyi = $\mathbf{0 , 0 0 2}<\mathbf{0 , 0 5}$ ). Yargılara tek tek bakıldığında sadece "bu birimde çalışan güvenliğine yönelik koruyucu ekipman mevcuttur" ifadesinde anlamlı bir fark olmadığı, bunun dışındaki diğer tüm yargılar anlamlı farklılıkların olduğu görülmektedir.

Çalışma hayatında en az bir kez iş kazasına uğrayanların, yönetimin sorumluluğu ifadelerinden "bu birimde çalışan güvenliğine yönelik koruyucu ekipman mevcuttur" ifadesi dışındaki tüm ifadelere 2,80 ortalama ile (katılmıyorum-fikrim yok arası) olumsuz cevap verdikleri, çalışma hayatında en az bir kez iş kazasına uğramayanların da, aynı ifadelere 3,28 ortalama ile (fikrim yok-katılıyorum arası) cevap verdikleri anlaşılmaktadır. Buna göre, çalışanlar uğradıkları iş kazalarında en büyük sorumlu olarak yönetimi görmektedirler.

\section{SONUÇ VE ÖNERILER}

Hastanelerde çalışan güvenliğini tehdit eden ve en sık karşılaşılan iş kazalarını tespit etmek, bu iş kazalarının oluşumunda, hastane yönetimi, çalışan güvenliği komitesi ve çalışanların sorumluluklarının çalışanlarca değerlendirilerek, gelişmeye açık alanları belirlemek ve hastanelerde çalışan güvenliği kültürünün gelişimine katkı sağlamak amacıyla yapılan çalışmanın sonuçları ve öneriler aşağıda sunulmuştur:

- Demografik veriler incelendiğinde, personel devir hızının yüksek olduğu görülmektedir. Dolayısıyla kurumların, çalışan güvenliği ile ilgili eğitimlerinin ve çalışan güvenliğini sağlamaya dönük kurumsal anlamda yapılan faaliyetlerinin devamlılığı sağlanmalıdır.

- İş kazalarına yönelik bulgular incelendiğinde sağlık personelleri arasında iş kazalarına maruz kalma oranlarının çok yüksek olduğu görülmektedir. Bu sonuç bu ve buna benzer çalışmaların önemini bir kez daha ortaya koymaktadır. Konu ile ilgili, çalışanların kurs, sempozyum, kongre, hizmet içi eğitim ve oryantasyon eğitimleri ile çalışan güvenliği konusunda bilgilenmeleri ve konunun sürekli gündemde tutulması sağlanmalıdır.

- Katılımcılar kurumlarında, şiddete maruz kalmanın özellikle de mobbingin oldukça yaygın olduğunu belirtmektedirler. Mobbing sağlık kurumlarında mücadele edilmesi gereken bir sorun olarak kabul edilmelidir. Bu konuda Başbakanlık 2011/2 sayılı 
“işyerlerinde psikolojik tacizin (mobbing) önlenmesi genelgesi ve TBMM'nin 2011 yılında yayımlamış olduğu “işyerinde psikolojik taciz(mobbing) ve çözüm önerileri raporu" doğrultusunda çalışmalar yapılmalıdır. Ayrıca TBMM tarafindan "sağlık çalışanlarına yönelik artan şiddet olaylarının araştırılarak alınması gereken önlemlerin belirlenmesi amacıyla 2013 yılında kurulan meclis araştırma komisyonu raporu" sonuçları ve önerileri doğrultusunda kurumsal politikalar belirlenmelidir.

- Katılımcıların \%45'inin “çalışan güvenliği komitesince olay bildirim sistemi kurulmuştur" ifadesine katıldıkları, fakat son bir yılda en az bir kez iş kazasına uğrayan katılımcıların \%83'ünün olay bildiriminde bulunmadığı anlaşılmaktadır. Çalışanların olay bildiriminde bulunmamaları ile ilgili kök neden analizleri yapılmalıdır. Olay bildirim kültürü kurumda oturtulmalıdır. Son yıllarda kurumlarında olay bildirim kültürünü oturtmuş birçok kamu kurumu bulunmaktadır. Bu kurumların uygulamaları incelenerek, bilgi paylaşımında bulunulmalıdır.

- Katılımcıların \%39'unun "hastanemizde çalışan güvenliği komitesi vardır” ifadesine katılmamaları dikkat çekicidir. Yine katılımcıların \%61'inin “çalışan güvenliği komitesince bölüm bazında riskleri belirlemek üzere çalışan ziyaretleri yapılmaktadır" ifadesine katılmadığı anlaşılmaktadır. Bu durum bize kurumlarda çalışan güvenliği komitesinin aktif olarak çalışmadığını göstermektedir. Hastanelerde "çalışan güvenliği komitesinin" aktif olarak çalışması sağlanmalıdır.

- Hastanelerde genel olarak hastane yönetimlerinin çalışan güvenliği ile ilgili tedbirleri almakta yeteri kadar aktif olmadıkları görülmektedir. Yürürlükteki mevzuatlara göre çalışanların iş sağlığı ve güvenliği için gerekli önlemleri almak öncelikle yönetimlerin sorumluluğundadır². Hastane yönetimleri konu ile ilgili hukuki sorumlulukları ve sonuçları açısından bilgilendirilmelidir.

- Araştırma, belirli bir zaman diliminde Karabük il merkezinde bulunan kamu hastanelerinde yapılmıştır. Farklı şehirlerde, farklı zamanlarda daha farklı sonuçlara ulaşılabilir. Benzer çalışmaların daha büyük örneklemde, Karabük dışındaki kamu ve özel hastanelerde yapılması araştırmacılara tavsiye edilmektedir.

${ }^{2}$ Ayrıntılı bilgi için bkz.Hakeri, Hakan, Sağlıkta Performans ve Kalite Dergisi S.1 s.53-59, Ocak 2010, Ankara. 


\section{KAYNAKÇA}

Akgün M., Arslanoğlu A., Dağlı G., (2011) “Merkezi Sterilizasyon Ünitesinde Çalışan Güvenliği” III. Uluslararası Sağlıkta Performans ve Kalite Kongresi Sözel Bildiriler Kitabı, s.92-106, Ankara.

Alpsoy L., Çolak M., (2013), “6331 Sayılı İş Sağlığı ve Güvenliği Kanunu”, Denetler Yayıncılık, İzmir.

Çınar F., Özlem A., Hatun M., İhsan B., (2011), "Kalp Hastanesinde Çalışan Sağlık Personelinin Çalışan Güvenliği Algı Düzeyi ile Çalışan Memnuniyeti Arasındaki İlişki” III. Uluslararası Katılımlı Sağlıkta Kalite, Akreditasyon ve Hasta Güvenliği Kongresi Poster Bildiriler Kitabı s.279-295, Ankara.

Devebakan N., (2007), “Özel Sağlık İşletmelerinde İş Sağlığı ve Güvenliği”” Dokuz Eylül Üniv., SBE, Çalışma Ekonomisi ve Endüstri İlişkileri ABD, Yayımlanmamış Doktora Tezi.

Dursun S., (2011) Güvenlik Kültürünün Güvenlik Performansı Üzerine Etkisine Yönelik Bir Uygulama, Uludağ Üniversitesi, SBE, Çalışma Ekonomisi ve Endüstri İlişkileri Ana Bilim Dalı, Yayımlanmamış Doktora Tezi.

Hakeri H., (2010), "Sağlık Çalışanı Güvenliği ve Hukuksal Sorumluluk” Sağlıkta Performans ve Kalite Dergisi Ocak S.1 s.53-59, Ankara.

Hastane Hizmet Kalite Standartları (2008), Sağlık Bakanlığı, Sağlık Bakanlığı, Tedavi Hizmetleri Genel Müdürlüğü, Performans Yönetimi ve Kalite Geliştirme Daire Başkanlığı.

Koraşlı D., Elif T., Ganime Y., (2010), "Sağlık Çalışanlarının Hasta Güvenliği Kültürü Algılamasının Değerlendirilmesi: Eğitim ve Araştırma Hastanesi Örneği” II. Sağlıkta Performans ve Kalite Kongresi Bildiriler Kitab1 s.442-454

Nakip M., (2006) Pazarlama Araştırmaları Teknikler ve (SPSS Destekli) Uygulamalar, 2. Baskı, Seçkin Yayınları, Ankara.

Sağlık Bakanlığı, Tedavi Hizmetleri Genel Müdürlüğü, Performans Yönetimi ve Kalite Geliştirme Daire Başkanlığı (2011), 1.HKS Okulu Ders Notlar1, Ankara.

Türkiye Büyük Millet Meclisi Kadın Erkek Fırsat Eşitliği Komisyonu (2011), "İşyerinde Psikolojik Taciz (Mobbing) ve Çözüm Önerileri Komisyon Raporu” Kadın Erkek Fırsat Eşitliği Komisyon Yayınları No:6, Ankara.

Türkiye Büyük Millet Meclisi Sağlık Çalışanlarına Yönelik Artan Şiddet Olaylarının Araştırılarak Alınması Gereken Önlemlerin Belirlenmesi Komisyonu (2013), Meclis Araştırması Komisyonu Raporu, Sıra Sayısı 454, Ankara.

Yavuz E., (2009), "Bir Üniversite Hastanesinde Çalışan Hemşirelerin İş Sağlığı ve İş Güvenliği Durumlarının İncelenmesi” Haliç Üniversitesi, SBE, Hemşirelik ABD, Yayımlanmamış Yüksek Lisans Tezi.

06.04.2011 tarih ve 27897 sayılı Resmi Gazetede yayımlanan "Hasta ve Çalışan Güvenliğinin Sağlanmasına Dair Yönetmelik"

Özkılıç, Özlem (2005), "İş Sağlığı ve İş Güvenliği, Yönetim Sistemleri ve Risk Değerlendirme Metodolojileri” www.tisk.org.tr/download/yayinlar/is_sagligi_ve guvenligi_metodolojileri.pdf (16.06.2012)

http://www.ctf.edu.tr/ctfhemhzmd/calisan_guvenligi.html (17.06.2012)

http://www.performans.saglik.gov.tr/content/files/duyurular_2011/2009/21_Agustos_2009/hanifi_aktas.pdf $(17.06 .2012)$

$\underline{\text { http://www.turksagliksen.org.tr/haberler/sendikamizdan-haberler/10744-saglik-muhabirleri-ile-bir-araya-geldik.html }}$ $(09.07 .2013)$ 
SGK 2012 yılı istatistik yılllğı, www.sgk.gov.tr $(17.06 .2013)$ 